University of Nebraska - Lincoln

DigitalCommons@University of Nebraska - Lincoln

Yasar Demirel Publications

Chemical and Biomolecular Research Papers --

Faculty Authors Series

2011

\title{
A Novel Biodiesel and Glycerol Carbonate Production Plant
}

Nghi T. Nguyen

University of Nebraska - Lincoln, nghinguyen1985@yahoo.com

Yasar Demirel

University of Nebraska - Lincoln, ydemirel2@unl.edu

Follow this and additional works at: https://digitalcommons.unl.edu/cbmedemirel

Part of the Chemical Engineering Commons

Nguyen, Nghi T. and Demirel, Yasar, "A Novel Biodiesel and Glycerol Carbonate Production Plant" (2011). Yasar Demirel Publications. 4.

https://digitalcommons.unl.edu/cbmedemirel/4

This Article is brought to you for free and open access by the Chemical and Biomolecular Research Papers -- Faculty Authors Series at DigitalCommons@University of Nebraska - Lincoln. It has been accepted for inclusion in Yasar Demirel Publications by an authorized administrator of DigitalCommons@University of Nebraska - Lincoln. 


\title{
INTERNATIONAL JOURNAL OF CHEMICAL REACTOR ENGINEERING
}

\section{A Novel Biodiesel and Glycerol Carbonate Production Plant}

\author{
Nghi T. Nguyen* $\quad$ Yasar Demirel $^{\dagger}$
}

*University of Nebraska-Lincoln, nghinguyen1985@yahoo.com

†University of Nebraska-Lincoln, ydemirel2@unl.edu

ISSN 1542-6580

Copyright @ 2011 De Gruyter. All rights reserved. 


\title{
A Novel Biodiesel and Glycerol Carbonate Production Plant
}

\author{
Nghi T. Nguyen and Yasar Demirel
}

\begin{abstract}
Crude glycerol is the byproduct of biodiesel production plant and the economic value of glycerol may affect the profitability of the biodiesel production plant. As the production rate of bioglycerol increases, its market values drop considerably. Therefore, conversion of bioglycerol into value-added products can reduce the overall cost, hence, leading to a more economical biodiesel production plant. In a direct carboxylation reaction, $\mathrm{CO}_{2}$ reacts with glycerol to produce glycerol carbonate and water. This study presents a direct comparison of the economic analysis of the conventional biodiesel production plant and the possible next generation biodiesel-glycerol carbonate production plant. At the end of 15-year project, the net present value of the biodiesel-glycerol carbonate production plant is $\$ 13.21$ million higher than the conventional biodiesel plant. The stochastic model has predicted that the biodiesel-glycerol carbonate and conventional biodiesel production plants has about $30 \%$ and $63 \%$ chance of getting negative net present value, respectively. Heterogeneous catalyst, $\mathrm{Ca}_{3} \mathrm{La}_{1}$, is used for transesterification reaction to reduce separation steps in the biodiesel production process.
\end{abstract}

KEYWORDS: biodiesel, carboxylation of bioglycerol, n-dibutyltin(IV)oxide, heterogeneous catalyst, glycerol carbonate, economic analysis 


\section{Introduction}

About $1 \mathrm{~kg}$ of glycerol is formed for every $10 \mathrm{~kg}$ of biodiesel produced (Nguyen and Demirel, 2010a). There is an inverse relationship between the production cost of biodiesel and the variations in the market value of bioglycerol. The production cost of biodiesel increases by $\$ 0.008 /$ gal for every $\$ 0.01 / 1$ b reduction in glycerol selling price (Zheng et al., 2008). Therefore, economical utilization schemes of bioglycerol, such as carboxylation of bioglycerol to bioglycerol carbonate, can lead to a more economical biodiesel production.

Glycerol is a low toxicity polyol compound that can be used to produce polymers, ethers, hydrogen, bioglycerol carbonate and various fine chemical compounds by selective glycerol-based catalytic processes such as dehydration, hydrogenolysis, esterification, oxidation, and carboxylation (Chun-Hui et al., 2008; Olga et al., 2009). Direct carboxylation of carbon dioxide $\left(\mathrm{CO}_{2}\right)$ and bioglycerol to yield water and glycerol carbonate is one of the most environmentally friendly processes due to the consumption of the two byproducts, $\mathrm{CO}_{2}$ and bioglycerol (Aresta et al., 2006; George et al., 2009; Vieville et al., 1998). So far, only 35\% conversion has been reported when the reaction proceeds at high pressure and high temperature (George et al., 2009). Therefore, development of a more robust catalyst for direct carboxylation is desirable (Dibenedetto et al., 2011).

Glycerol carbonate is an intermediate chemical with many potential areas of application, such as, reactive protic solvent, a substitute for ethylene carbonate, propylene carbonate, cyclocarbonate derivatives, solvents for battery electrolyte, filming lubricants, filing plastifiers, agrosynthons, ingredients for cosmetics, and monomers for polymerization. It is also a novel component of gas separation membranes, coatings, paints and surfactants. It can act as a nonvolatile reactive solvent for several types of materials. In addition, it could serve as a source of new polymeric materials for the production of polycarbonates and polyurethanes (Chun-Hui et al., 2008; Olga et al., 2009).

\section{Reactions}

\subsection{Transesterification}

Utilizing conventional homogeneous catalyst such as $\mathrm{NaOH}$ or $\mathrm{KOH}$ in transesterification requires at least three distillation columns and produces large amounts of waste water (Lee and Saka, 2010; Zhang et al., 2003). Beside, the homogeneous catalyst is not reusable. Unlike homogeneous catalyst, heterogeneous catalyst can be regenerated and reused leading to reduction in 
separation steps and simplified biodiesel production process (Rajabathar and Ming, 2009; Yan et al., 2010; Zabeti et al., 2009). However, using heterogeneous catalyst requires higher alcohol/oil molar ratio (Di Serio et al., 2008; Sharma et al., 2010). In this study, lanthanum calcium oxide is used to catalyze the transesterification reaction, shown below

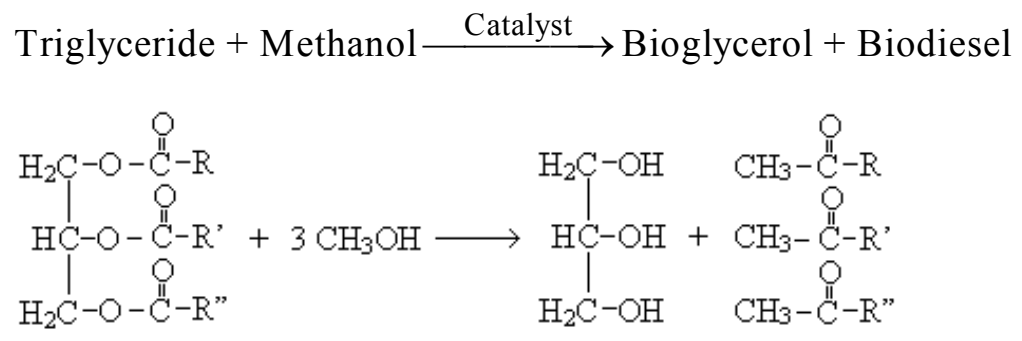

Lanthanum calcium oxides show high activity even in the presence of water, tolerating up to $3.6 \%$ on the weight basis of free fatty acid. They are highly stable, can be reused three times in a batch stirred reactor, and highly active for 14 days in a continuous fixed bed reactor, which may be suitable for industrial application (Yan et al., 2009; Yan et al., 2010a; Yan et al., 2010b). The optimum calcium to lanthanum molar ratio is 3 to $1\left(\mathrm{Ca}_{3} \mathrm{La}_{1}\right)$ (Yan et al., 2010b). $94.3 \%$ conversion of oil is achieved when the reaction proceeds at $58{ }^{\circ} \mathrm{C}$ and 1 bar for 1 hour using $5 \%$ weight of $\mathrm{Ca}_{3} \mathrm{La}_{1}$ catalyst. The molar ratio of methanol to oil is 20:1 (Yan et al., 2009). In term of economic comparison, the cost of $\mathrm{Ca}_{3} \mathrm{La}_{1}$ is irrelevant since both plants use the same amount of catalyst and the net present value will increase proportionally.

\subsection{Carboxylation}

Under optimum conditions, maximum conversion for the direct carboxylation of bioglycerol in the presence of tin catalysts such as $n-\mathrm{Bu}_{2} \mathrm{Sn}(\mathrm{OMe})_{2}$ is around 7 to 10 percent (Aresta et al., 2006; Dibenedotto et al., 2011).

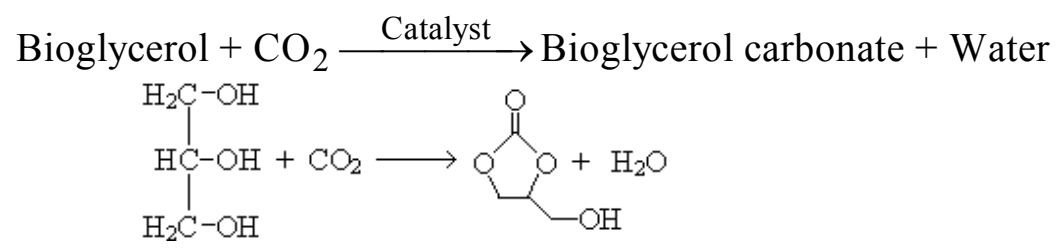

A conversion of $32.15 \%$ can be achieved under supercritical $\mathrm{CO}_{2}$ in the presence of zeolites and ion exchange resins (Vieville et al., 1998). However, excessive pressure results in higher equipment and operating costs. Finding a 
stable catalyst with a reasonable yield is crucial for reusing the catalyst and obtaining high conversion of bioglycerol. A recent study shows that 35\% conversion is possible at $80{ }^{\circ} \mathrm{C}$ and $3.5 \mathrm{MPa}$ using $1 \mathrm{~mol} \%$ of $n$ dibutyltin(IV)oxide ( $\left.\mathrm{n}-\mathrm{Bu}_{2} \mathrm{SnO}\right)$ and methanol as solvent (George et al., 2009).

\section{Base case and novel biodiesel production plants}

\subsection{Base case biodiesel production plant}

The base case biodiesel production plant, shown in Fig. 1, utilizes methanol and triglyceride to produce fatty acid methyl ester (FAME) and glycerol using lanthanum calcium oxides as catalyst. Recycled and fresh methanol and oil are mixed in mixers M101 and M102 before they are fed into the reactor R101. Under $58{ }^{\circ} \mathrm{C}$ and 1 bar, $94.3 \%$ conversion of triglyceride is achieved (Yan et al., 2009). The reactor effluent, stream S3, containing mixture of catalyst, products, and unreacted reactants, is sent to separator SEP101 to recover $\mathrm{Ca}_{3} \mathrm{La}_{1}$. The outlet stream S4 enters flash drum F101 to recover the excess methanol. Fig. 2 shows that both the molar flow rates of methanol and glycerol in the recycle stream R3 increase as the temperature of the flash drum, F101, increases. The increase in the molar flow rate of glycerol in stream R3 is relatively sharper after $129{ }^{\circ} \mathrm{C}$ as indicated in Fig. 2b. Therefore, the operating temperature of the flash drum, F101, is set to $128.35{ }^{\circ} \mathrm{C}$ by a design specification block to control the flow rate of glycerol in stream R3.

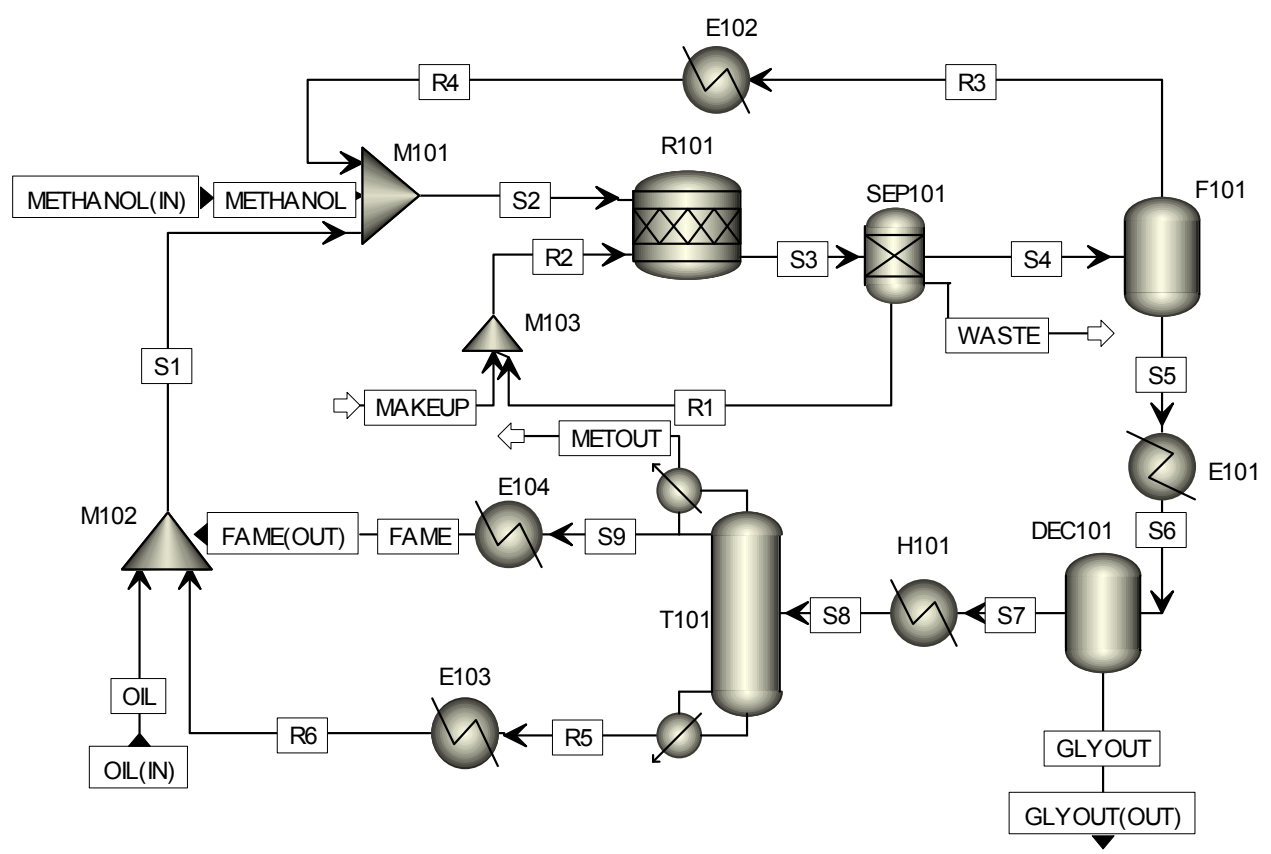

Fig. 1. Process flow diagram of the base case biodiesel production plant 
The bottom product (S5) of the flash drum, F101, is cooled to $25{ }^{\circ} \mathrm{C}$ in cooler E101before it is sent to the decanter DEC101 to separate glycerol. Stream $\mathrm{S} 7$, containing unused oil, FAME, and methanol, is preheated to $300{ }^{\circ} \mathrm{C}$ before feeding to distillation column T101 to minimize exergy losses caused by the temperature gradient (Bandyopadhyay et al., 1998; Demirel, 2006; Nguyen and Demirel, 2010b; Nguyen and Demirel, 2011). Distillation column T101 operates with 5 equilibrium stages with a partial-vapor-liquid condenser and a kettle reboiler. The following two design specifications are used to control the top and bottom flow rates of the distillation column, T101. The first design specification sets the flow rate of FAME in stream R5 to $0.29 \mathrm{kmol} / \mathrm{hr}$ by varying the distillate flow rate. The second design specification sets the flow rate of FAME to 0.1 $\mathrm{kmol} / \mathrm{hr}$ in stream METOUT by varying the distillate vapor fraction. The distillate flow rate is $20.96 \mathrm{kmol} / \mathrm{hr}$ and the distillate vapor fraction is 0.0129 . The bottom stream containing mostly oil is recycled. The stream properties are summarized in Table 1, which is obtained by using Aspen Plus V7.2 with the thermodynamic model of UNIF-DMD. The activity coefficient model NRTL-RK model is used to estimate the vapor and liquid properties in column T101. Table 1 lists the streams used in the process flow diagram shown in Fig. 1. Overall, the base case biodiesel production plant consumes $704.88 \mathrm{~kg} / \mathrm{hr}$ of methanol and $6074.47 \mathrm{~kg} / \mathrm{hr}$ of oil to produce $6079.70 \mathrm{~kg} / \mathrm{hr}$ of FAME and $664.55 \mathrm{~kg} / \mathrm{hr}$ of crude bioglycerol as indicated in Table 1.

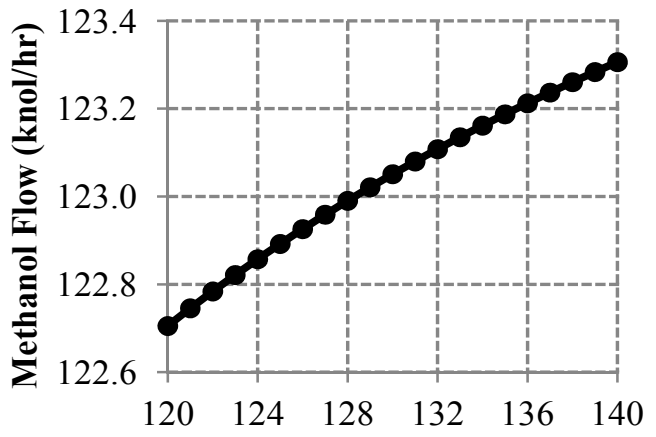

Flash F101 Temperature $\left({ }^{0} \mathrm{C}\right)$

(a)

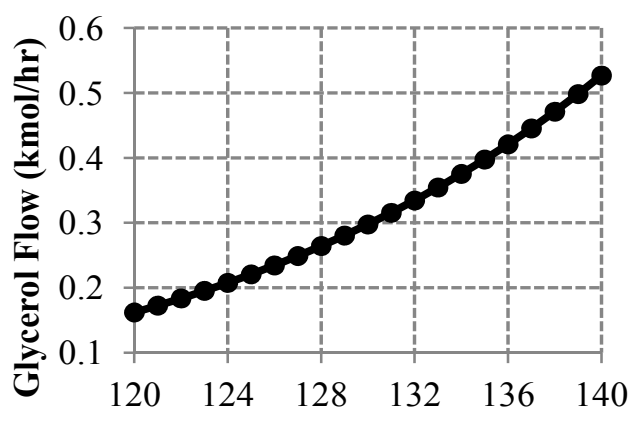

Flash F101 Temperature $\left({ }^{0} \mathrm{C}\right)$

(b)

Fig. 2. Sensivity analysis of flash column F101 temperature on: (a) molar flow rate of methanol in stream R3; (b) molar flow rate of glycerol in stream R3. 
Table 1

Streams properties of the base case biodiesel production plant shown in Fig. 1.

\begin{tabular}{lccccccccc}
\hline & FAME & GLYOUT & METHANOL & METOUT & OIL & R3 & R4 & R5 & R6 \\
\hline Total Flow kg/hr & 6079.70 & 664.55 & 704.88 & 35.10 & 6074.47 & 3999.72 & 3999.72 & 431.02 & 431.02 \\
Temperature C & 25.00 & 25.00 & 25.00 & 301.75 & 25.00 & 128.35 & 25.00 & 385.49 & 25.00 \\
Pressure bar & 1 & 1 & 1 & 1 & 1 & 0.5 & 1 & 1 & 1 \\
Liquid Frac & 1 & 1 & 1 & 0 & 1 & 0 & 1 & 1 & 1 \\
Mass Flow kg/hr & & & & & & & & & \\
METHANOL & $6.89 \mathrm{E}+00$ & $3.36 \mathrm{E}+01$ & $7.05 \mathrm{E}+02$ & $5.44 \mathrm{E}+00$ & $0.00 \mathrm{E}+00$ & $3.94 \mathrm{E}+03$ & $3.94 \mathrm{E}+03$ & $3.98 \mathrm{E}-07$ & $3.98 \mathrm{E}-07$ \\
OIL & $4.94 \mathrm{E}+00$ & $3.83 \mathrm{E}-12$ & $0.00 \mathrm{E}+00$ & $3.56 \mathrm{E}-03$ & $6.07 \mathrm{E}+03$ & $1.69 \mathrm{E}+01$ & $1.69 \mathrm{E}+01$ & $3.45 \mathrm{E}+02$ & $3.45 \mathrm{E}+02$ \\
FAME & $6.07 \mathrm{E}+03$ & $6.10 \mathrm{E}-03$ & $0.00 \mathrm{E}+00$ & $2.96 \mathrm{E}+01$ & $0.00 \mathrm{E}+00$ & $1.67 \mathrm{E}+01$ & $1.67 \mathrm{E}+01$ & $8.60 \mathrm{E}+01$ & $8.60 \mathrm{E}+01$ \\
GLYCEROL & $3.66 \mathrm{E}-01$ & $6.31 \mathrm{E}+02$ & $0.00 \mathrm{E}+00$ & $7.07 \mathrm{E}-03$ & $0.00 \mathrm{E}+00$ & $2.49 \mathrm{E}+01$ & $2.49 \mathrm{E}+01$ & $2.42 \mathrm{E}-05$ & $2.42 \mathrm{E}-05$ \\
Mass Frac & & & & & & & & & \\
METHANOL & 0.0011 & 0.0506 & 1.0000 & 0.1549 & 0.0000 & 0.9854 & 0.9854 & 0.0000 & 0.0000 \\
OIL & 0.0008 & 0.0000 & 0.0000 & 0.0001 & 1.0000 & 0.0042 & 0.0042 & 0.8005 & 0.8005 \\
FAME & 0.9980 & 0.0000 & 0.0000 & 0.8448 & 0.0000 & 0.0042 & 0.0042 & 0.1995 & 0.1995 \\
GLYCEROL & 0.0001 & 0.9494 & 0.0000 & 0.0002 & 0.0000 & 0.0062 & 0.0062 & 0.0000 & 0.0000 \\
\hline
\end{tabular}

\begin{tabular}{lccccccccc}
\hline & $\mathrm{S} 1$ & $\mathrm{~S} 2$ & $\mathrm{~S} 3$ & $\mathrm{~S} 4$ & $\mathrm{~S} 5$ & $\mathrm{~S} 6$ & $\mathrm{~S} 7$ & $\mathrm{~S} 8$ & $\mathrm{~S} 9$ \\
\hline Total Flow kg/hr & 6505.49 & 11210.09 & 11530.48 & 11210.09 & 7210.36 & 7210.36 & 6545.81 & 6545.81 & 6079.70 \\
Temperature C & 25.00 & 22.51 & 58.00 & 58.00 & 128.35 & 25.00 & 25.00 & 300.00 & 301.75 \\
Pressure bar & 1 & 1 & 1 & 1 & 0.5 & 1 & 1 & 1 & 1 \\
Liquid Frac & 1 & 1 & 1 & 1 & 1 & 1 & 1 & 1 & 1 \\
Mass Flow kg/hr & & & & & & & & & \\
METHANOL & $3.98 \mathrm{E}-07$ & $4.65 \mathrm{E}+03$ & $3.99 \mathrm{E}+03$ & $3.99 \mathrm{E}+03$ & $4.60 \mathrm{E}+01$ & $4.60 \mathrm{E}+01$ & $1.23 \mathrm{E}+01$ & $1.23 \mathrm{E}+01$ & $6.89 \mathrm{E}+00$ \\
OIL & $6.42 \mathrm{E}+03$ & $6.44 \mathrm{E}+03$ & $3.67 \mathrm{E}+02$ & $3.67 \mathrm{E}+02$ & $3.50 \mathrm{E}+02$ & $3.50 \mathrm{E}+02$ & $3.50 \mathrm{E}+02$ & $3.50 \mathrm{E}+02$ & $4.94 \mathrm{E}+00$ \\
FAME & $8.60 \mathrm{E}+01$ & $1.03 \mathrm{E}+02$ & $6.20 \mathrm{E}+03$ & $6.20 \mathrm{E}+03$ & $6.18 \mathrm{E}+03$ & $6.18 \mathrm{E}+03$ & $6.18 \mathrm{E}+03$ & $6.18 \mathrm{E}+03$ & $6.07 \mathrm{E}+03$ \\
GLYCEROL & $2.42 \mathrm{E}-05$ & $2.49 \mathrm{E}+01$ & $6.56 \mathrm{E}+02$ & $6.56 \mathrm{E}+02$ & $6.31 \mathrm{E}+02$ & $6.31 \mathrm{E}+02$ & $3.73 \mathrm{E}-01$ & $3.73 \mathrm{E}-01$ & $3.66 \mathrm{E}-01$ \\
Mass Frac & & & & & & & & & \\
METHANOL & 0.0000 & 0.4145 & 0.3458 & 0.3557 & 0.0064 & 0.0064 & 0.0019 & 0.0019 & 0.0011 \\
OIL & 0.9868 & 0.5742 & 0.0318 & 0.0327 & 0.0485 & 0.0485 & 0.0535 & 0.0535 & 0.0008 \\
FAME & 0.0132 & 0.0092 & 0.5377 & 0.5531 & 0.8575 & 0.8575 & 0.9446 & 0.9446 & 0.9980 \\
GLYCEROL & 0.0000 & 0.0022 & 0.0569 & 0.0585 & 0.0876 & 0.0876 & 0.0001 & 0.0001 & 0.0001 \\
\hline
\end{tabular}




\subsection{Novel biodiesel production plant}

The novel biodiesel production plant contains two sections as shown in Fig. 3a. Section 1 (Fig. 3b) produces biodiesel and crude bioglycerol and Section 2 (Fig. $3 c)$ produces bioglycerol carbonate and water. As seen in Fig. 3b, the locations of the decanter DEC101 and flash drum F101 are switched because of the separation of methanol from glycerol is undesirable since the methanol will be used as a solvent for the direct carboxylation of glycerol in Section 2. Section 1 of the novel biodiesel production plant uses $1050.98 \mathrm{~kg} / \mathrm{hr}$ of methanol and $6062.43 \mathrm{~kg} / \mathrm{hr}$ of oil to produce $6025.63 \mathrm{~kg} / \mathrm{hr}$ of FAME and $4117.86 \mathrm{~kg} / \mathrm{hr}$ of the stream, BYPROD, containing $83.55 \% \mathrm{wt}$ methanol as summarized in Table 2.

In section 2 (Fig. 3c), the stream GLYMET is mixed with the recycle stream R4 in mixer M201, and it is pressurized and heated to the reaction temperature before entering reactor R201. Stream GLYMET contains, by mass, $83.5 \%$ of methanol and $15.29 \%$ of glycerol, while stream R4 contains $96.6 \%$ glycerol. Carbon dioxide $\left(\mathrm{CO}_{2}\right)$ is compressed to 35 bars in compressor COM201 and cooled to $80{ }^{\circ} \mathrm{C}$ in cooler E201 before it is fed to reactor R201. The carboxylation reaction takes place at $80^{\circ} \mathrm{C}$ and $3.5 \mathrm{MPa}$ of $\mathrm{CO}_{2}$ using methanol as a solvent and 1 mole percent of n-dibutyltin(IV)oxide as catalyst. The methanol/glycerol molar ratio of 11.41 (in stream S3) is used in this simulation while 11.38 is used by George et al., 2009. However, only $25 \%$ conversion is assumed in this simulation because of the ongoing research on the level of conversion achievable with the catalyst n-dibutyltin(IV)oxide (Dibenedetto et al., 2011). Separator SEP201 is used to separate the catalyst from the reactor outlet with $50 \%$ of recovered, treated, and recycled to the reactor. 


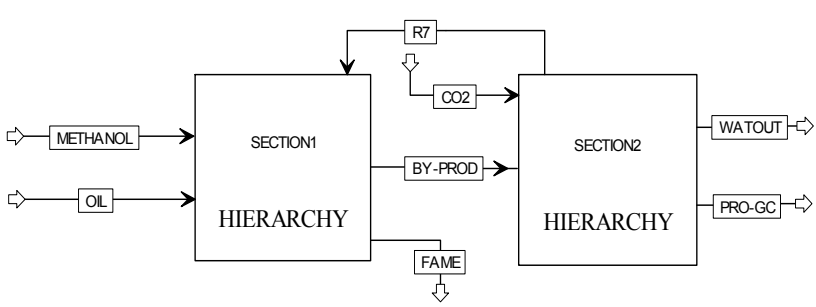

(a)

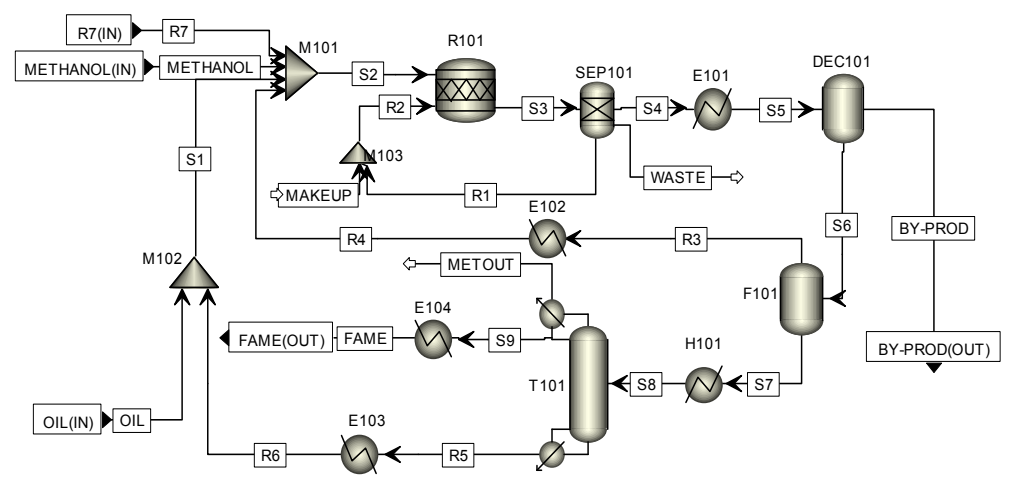

(b)

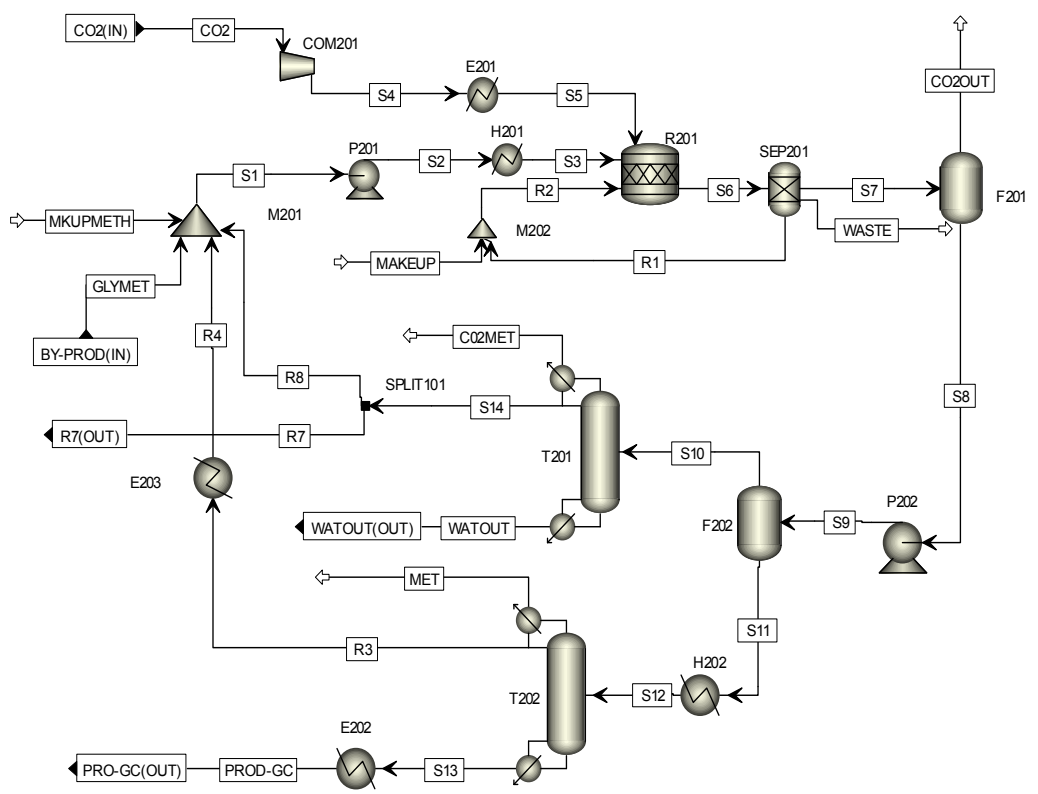

(c)

Fig. 3. (a) Hierarchy of the novel biodiesel production plant; (b) process flow diagram of Section 1 for biodiesel and bioglycerol production plant; (c) process flow diagram of Section 2 for bioglycerol carbonate production plant. 
Design specification is set on flash drum F201 to control the flow rate of $\mathrm{CO}_{2}$ by varying the column operating pressure. Flash drum F201 removes excess $\mathrm{CO}_{2}$ operating at an absolute pressure of 0.181 bar. The bottom product of F201, stream S8, is pressurized to 1 bar in pump P202 upon entering flash drum F202 to separate water and methanol from glycerol and glycerol carbonate. The top product of T201, stream S10, containing methanol and water is fed to distillation column T201 at stage 5. Column T201 operates with 7 equilibrium stages with a kettle reboiler and a partial vapor-liquid condenser. The reboiler and condenser duties are $7,570.47 \mathrm{~kW}$ and $10,104.74 \mathrm{~kW}$, respectively. The NRTL-RK model is used to predict the phase-equilibrium in distillation column T201. The distillate of T201, stream R7, contains high concentration of methanol, and is recycled to Section 1, while streams CO2MET and WATOUT are treated as waste.

The bottom product of flash column F202, stream S11, is preheated to $240^{\circ} \mathrm{C}$, and fed to stage 10 of distillation column T202 (Bandyopadhyay et al., 1998; Demirel, 2006; Nguyen and Demirel, 2010b; Nguyen and Demirel, 2011). The column T202 has 16 stages. The distillate, stream R3, contains mostly glycerol, which is recycled. The bottom product, stream S13, with a flow rate of $649.69 \mathrm{~kg} / \mathrm{hr}$ and $93.54 \%$ on the weight basis is the glycerol carbonate. Glycerol carbonate properties are approximated based on the structural information obtained using the group contribution model of UNIF-DMD. The glycerol carbonate production section (Section 2) utilizes $273.74 \mathrm{~kg} / \mathrm{hr}$ of carbon dioxide and $4117.86 \mathrm{~kg} / \mathrm{hr}$ of glycerol and methanol to produce $649.69 \mathrm{~kg} / \mathrm{hr}$ of glycerol carbonate and $209.51 \mathrm{~kg} / \mathrm{hr}$ of water as shown in Table 3. Aspen Plus V7.2 is used for all the simulations. 
Table 2

Streams properties of the novel biodiesel production plant (Section 1) shown in Fig. $3 \mathrm{~b}$.

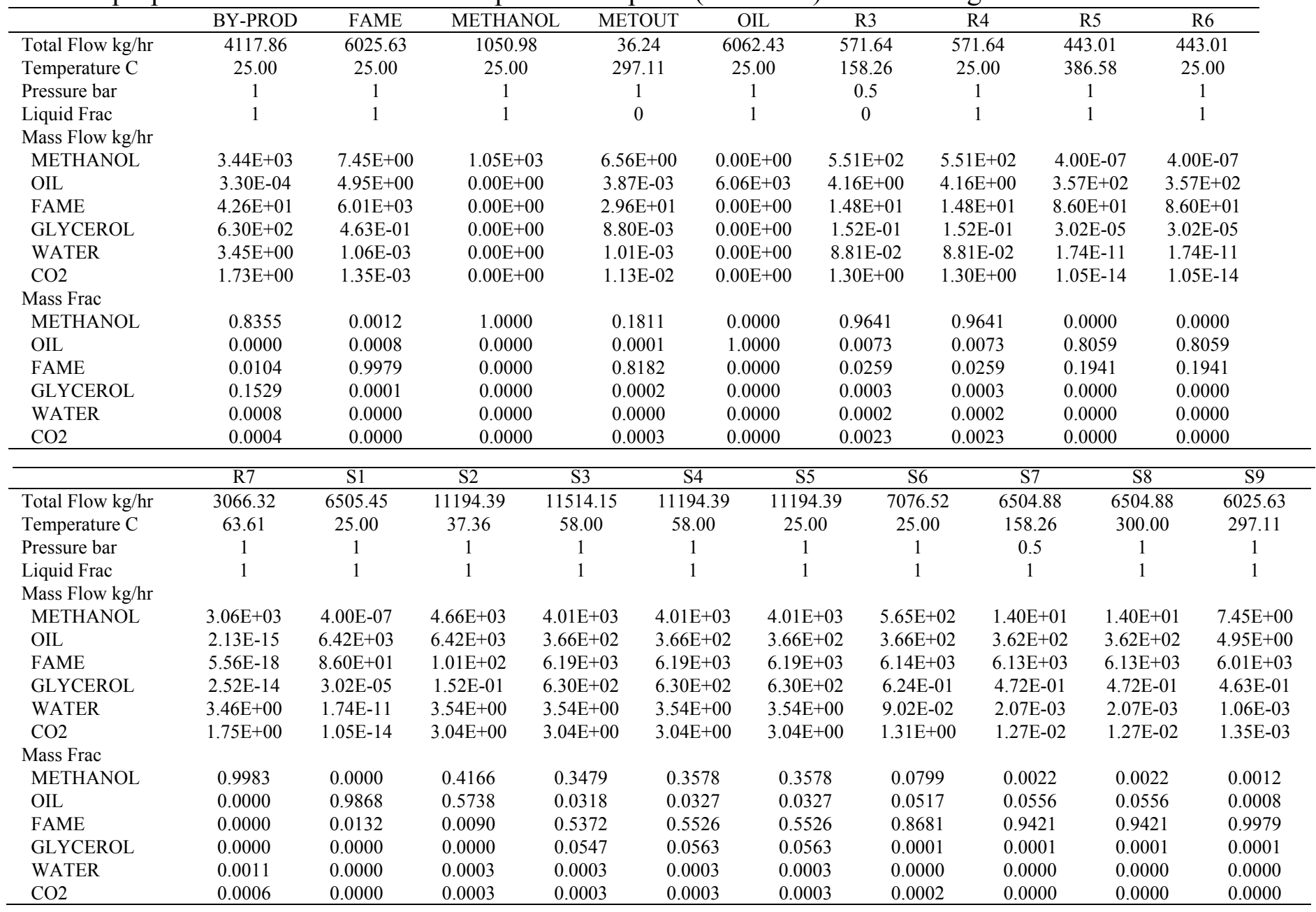


Table 3

Streams properties of the glycerol carbonate production plant (Section 2) shown in Fig. 3c.

\begin{tabular}{|c|c|c|c|c|c|c|c|c|c|c|c|c|c|}
\hline & CO2MET & $\mathrm{CO} 2$ & CO2OUT & GLYMET & MET & MKUPMETH & PROD-GC & R3 & R4 & R7 & R8 & $\mathrm{S} 1$ & S2 \\
\hline Total Flow $\mathrm{kg} / \mathrm{hr}$ & 164.94 & 273.74 & 173.49 & 4117.86 & 147.70 & 19.81 & 649.69 & 1334.84 & 1334.84 & 3066.32 & 4124.73 & 9597.25 & 9597.25 \\
\hline Temperature C & 63.84 & 25.00 & 25.00 & 25.00 & 255.51 & 25.00 & 25.00 & 255.51 & 25.00 & 63.61 & 63.61 & 43.37 & 45.46 \\
\hline Pressure bar & 1 & 1 & 0.18 & 1 & 1 & 1 & 1 & 1 & 1 & 1 & 1 & 1 & 35 \\
\hline Liquid Frac & 0 & 0 & 0 & 1 & 0 & 1 & 1 & 1 & 1 & 1 & 1 & 1 & 1 \\
\hline \multicolumn{14}{|l|}{ Mass Flow $\mathrm{kg} / \mathrm{hr}$} \\
\hline METHANOL & $1.60 \mathrm{E}+02$ & $0.00 \mathrm{E}+00$ & $1.33 \mathrm{E}+02$ & $3.44 \mathrm{E}+03$ & $6.73 \mathrm{E}+01$ & $1.98 \mathrm{E}+01$ & 9.93E-06 & $3.72 \mathrm{E}+01$ & $3.72 \mathrm{E}+01$ & $3.06 \mathrm{E}+03$ & $4.12 \mathrm{E}+03$ & $7.62 \mathrm{E}+03$ & $7.62 \mathrm{E}+03$ \\
\hline FAME & $3.25 \mathrm{E}-25$ & $0.00 \mathrm{E}+00$ & $3.90 \mathrm{E}-05$ & $4.26 \mathrm{E}+01$ & $1.66 \mathrm{E}-09$ & $0.00 \mathrm{E}+00$ & $3.57 \mathrm{E}+00$ & $3.47 \mathrm{E}-08$ & 3.47E-08 & $5.56 \mathrm{E}-18$ & 7.47E-18 & 4. $26 \mathrm{E}+01$ & $4.26 \mathrm{E}+01$ \\
\hline GLYCEROL & 2.13E-20 & $0.00 \mathrm{E}+00$ & 4.53E-05 & $6.30 \mathrm{E}+02$ & $7.92 \mathrm{E}+01$ & $0.00 \mathrm{E}+00$ & $3.84 \mathrm{E}+01$ & $1.29 \mathrm{E}+03$ & $1.29 \mathrm{E}+03$ & $2.52 \mathrm{E}-14$ & 3.39E-14 & $1.92 \mathrm{E}+03$ & $1.92 \mathrm{E}+03$ \\
\hline WATER & 4.42E-02 & $0.00 \mathrm{E}+00$ & $6.48 \mathrm{E}-01$ & $3.45 \mathrm{E}+00$ & $8.63 \mathrm{E}-01$ & $0.00 \mathrm{E}+00$ & $2.36 \mathrm{E}-15$ & $9.01 \mathrm{E}-02$ & $9.01 \mathrm{E}-02$ & $3.46 \mathrm{E}+00$ & $4.65 \mathrm{E}+00$ & $8.19 \mathrm{E}+00$ & $8.19 \mathrm{E}+00$ \\
\hline $\mathrm{CO} 2$ & $4.69 \mathrm{E}+00$ & $2.74 \mathrm{E}+02$ & $3.98 \mathrm{E}+01$ & $1.73 \mathrm{E}+00$ & $1.60 \mathrm{E}-02$ & $0.00 \mathrm{E}+00$ & $3.72 \mathrm{E}-24$ & $2.82 \mathrm{E}-04$ & $2.82 \mathrm{E}-04$ & $1.75 \mathrm{E}+00$ & $2.35 \mathrm{E}+00$ & $4.09 \mathrm{E}+00$ & $4.09 \mathrm{E}+00$ \\
\hline $\mathrm{GC}$ & $5.83 \mathrm{E}-23$ & $0.00 \mathrm{E}+00$ & $1.47 \mathrm{E}-05$ & $0.00 \mathrm{E}+00$ & $3.19 \mathrm{E}-01$ & $0.00 \mathrm{E}+00$ & $6.08 \mathrm{E}+02$ & $8.27 \mathrm{E}+00$ & $8.27 \mathrm{E}+00$ & $1.94 \mathrm{E}-16$ & $2.61 \mathrm{E}-16$ & $8.27 \mathrm{E}+00$ & $8.27 \mathrm{E}+00$ \\
\hline \multicolumn{14}{|l|}{ Mass Frac } \\
\hline METHANOL & 0.9713 & 0.0000 & 0.7670 & 0.8355 & 0.4553 & 1.0000 & 0.0000 & 0.0278 & 0.0278 & 0.9983 & 0.9983 & 0.7935 & 0.7935 \\
\hline FAME & 0.0000 & 0.0000 & 0.0000 & 0.0104 & 0.0000 & 0.0000 & 0.0055 & 0.0000 & 0.0000 & 0.0000 & 0.0000 & 0.0044 & 0.0044 \\
\hline GLYCEROL & 0.0000 & 0.0000 & 0.0000 & 0.1529 & 0.5366 & 0.0000 & 0.0591 & 0.9659 & 0.9659 & 0.0000 & 0.0000 & 0.1999 & 0.1999 \\
\hline WATER & 0.0003 & 0.0000 & 0.0037 & 0.0008 & 0.0058 & 0.0000 & 0.0000 & 0.0001 & 0.0001 & 0.0011 & 0.0011 & 0.0009 & 0.0009 \\
\hline $\mathrm{CO} 2$ & 0.0284 & 1.0000 & 0.2293 & 0.0004 & 0.0001 & 0.0000 & 0.0000 & 0.0000 & 0.0000 & 0.0006 & 0.0006 & 0.0004 & 0.0004 \\
\hline $\mathrm{GC}$ & 0.0000 & 0.0000 & 0.0000 & 0.0000 & 0.0022 & 0.0000 & 0.9354 & 0.0062 & 0.0062 & 0.0000 & 0.0000 & 0.0009 & 0.0009 \\
\hline
\end{tabular}

\begin{tabular}{|c|c|c|c|c|c|c|c|c|c|c|c|c|c|}
\hline & S3 & S4 & S5 & S6 & S7 & S8 & S9 & S10 & S11 & S12 & S13 & S14 & WATOUT \\
\hline Total Flow $\mathrm{kg} / \mathrm{hr}$ & 9597.25 & 273.74 & 273.74 & 9874.11 & 9870.99 & 9697.50 & 9697.50 & 7565.28 & 2132.23 & 2132.23 & 649.69 & 7191.05 & 209.51 \\
\hline Temperature C & 80.00 & 448.82 & 80.00 & 80.00 & 80.00 & 25.00 & 25.05 & 140.00 & 140.00 & 240.00 & 315.53 & 63.84 & 90.96 \\
\hline Pressure bar & 35 & 35 & 35 & 35 & 35 & 0.18 & 1 & 1 & 1 & 1 & 1 & 1 & 1 \\
\hline Liquid Frac & 1 & 0 & 0 & 1 & 1 & 1 & 1 & 0 & 1 & 0.90 & 1 & 1 & 1 \\
\hline \multicolumn{14}{|l|}{ Mass Flow kg/hr } \\
\hline METHANOL & $7.62 \mathrm{E}+03$ & $0.00 \mathrm{E}+00$ & $0.00 \mathrm{E}+00$ & $7.62 \mathrm{E}+03$ & $7.62 \mathrm{E}+03$ & $7.48 \mathrm{E}+03$ & $7.48 \mathrm{E}+03$ & $7.38 \mathrm{E}+03$ & $1.04 \mathrm{E}+02$ & $1.04 \mathrm{E}+02$ & $9.93 \mathrm{E}-06$ & $7.18 \mathrm{E}+03$ & $3.89 \mathrm{E}+01$ \\
\hline FAME & $4.26 \mathrm{E}+01$ & $0.00 \mathrm{E}+00$ & $0.00 \mathrm{E}+00$ & $4.26 \mathrm{E}+01$ & $4.26 \mathrm{E}+01$ & $4.26 \mathrm{E}+01$ & $4.26 \mathrm{E}+01$ & $3.91 \mathrm{E}+01$ & $3.57 \mathrm{E}+00$ & $3.57 \mathrm{E}+00$ & $3.57 \mathrm{E}+00$ & $1.30 \mathrm{E}-17$ & $3.91 \mathrm{E}+01$ \\
\hline GLYCEROL & $1.92 \mathrm{E}+03$ & $0.00 \mathrm{E}+00$ & $0.00 \mathrm{E}+00$ & $1.44 \mathrm{E}+03$ & $1.44 \mathrm{E}+03$ & $1.44 \mathrm{E}+03$ & $1.44 \mathrm{E}+03$ & $3.22 \mathrm{E}+01$ & $1.41 \mathrm{E}+03$ & $1.41 \mathrm{E}+03$ & $3.84 \mathrm{E}+01$ & $5.90 \mathrm{E}-14$ & $3.22 \mathrm{E}+01$ \\
\hline WATER & $8.19 \mathrm{E}+00$ & $0.00 \mathrm{E}+00$ & $0.00 \mathrm{E}+00$ & $1.02 \mathrm{E}+02$ & $1.02 \mathrm{E}+02$ & $1.01 \mathrm{E}+02$ & $1.01 \mathrm{E}+02$ & $1.00 \mathrm{E}+02$ & $9.54 \mathrm{E}-01$ & 9.54E-01 & $2.36 \mathrm{E}-15$ & $8.11 \mathrm{E}+00$ & $9.23 \mathrm{E}+01$ \\
\hline $\mathrm{CO} 2$ & $4.09 \mathrm{E}+00$ & $2.74 \mathrm{E}+02$ & $2.74 \mathrm{E}+02$ & $4.86 \mathrm{E}+01$ & $4.86 \mathrm{E}+01$ & $8.80 \mathrm{E}+00$ & $8.80 \mathrm{E}+00$ & $8.79 \mathrm{E}+00$ & $1.62 \mathrm{E}-02$ & $1.62 \mathrm{E}-02$ & $3.72 \mathrm{E}-24$ & $4.10 \mathrm{E}+00$ & $6.70 \mathrm{E}-09$ \\
\hline $\mathrm{GC}$ & $8.27 \mathrm{E}+00$ & $0.00 \mathrm{E}+00$ & $0.00 \mathrm{E}+00$ & $6.23 \mathrm{E}+02$ & $6.23 \mathrm{E}+02$ & $6.23 \mathrm{E}+02$ & $6.23 \mathrm{E}+02$ & $7.09 \mathrm{E}+00$ & $6.16 \mathrm{E}+02$ & $6.16 \mathrm{E}+02$ & $6.08 \mathrm{E}+02$ & $4.54 \mathrm{E}-16$ & $7.09 \mathrm{E}+00$ \\
\hline \multicolumn{14}{|l|}{ Mass Frac } \\
\hline METHANOL & 0.7935 & 0.0000 & 0.0000 & 0.7712 & 0.7715 & 0.7716 & 0.7716 & 0.9752 & 0.0490 & 0.0490 & 0.0000 & 0.9983 & 0.1855 \\
\hline FAME & 0.0044 & 0.0000 & 0.0000 & 0.0043 & 0.0043 & 0.0044 & 0.0044 & 0.0052 & 0.0017 & 0.0017 & 0.0055 & 0.0000 & 0.1865 \\
\hline GLYCEROL & 0.1999 & 0.0000 & 0.0000 & 0.1458 & 0.1458 & 0.1484 & 0.1484 & 0.0043 & 0.6599 & 0.6599 & 0.0591 & 0.0000 & 0.1537 \\
\hline WATER & 0.0009 & 0.0000 & 0.0000 & 0.0103 & 0.0103 & 0.0105 & 0.0105 & 0.0133 & 0.0004 & 0.0004 & 0.0000 & 0.0011 & 0.4405 \\
\hline $\mathrm{CO} 2$ & 0.0004 & 1.0000 & 1.0000 & 0.0049 & 0.0049 & 0.0009 & 0.0009 & 0.0012 & 0.0000 & 0.0000 & 0.0000 & 0.0006 & 0.0000 \\
\hline $\mathrm{GC}$ & 0.0009 & 0.0000 & 0.0000 & 0.0631 & 0.0632 & 0.0643 & 0.0643 & 0.0009 & 0.2890 & 0.2890 & 0.9354 & 0.0000 & 0.0338 \\
\hline
\end{tabular}




\section{Economic analysis}

\subsection{Deterministic model}

Fix capital investment (FCI) is set equal to the grassroots cost $\left(C_{G R}\right)$, which is approximated by the following equation (Turton et al., 2008)

$C_{G R}=1.68 \sum_{i=1}^{n} C_{B m, i}^{o}$

where $C_{B m, i}^{o}$ is the bare module cost of equipment $i$ at base conditions. The bare module costs of major equipment $C_{B m, i}^{o}$ are estimated using the CAPCOST 2008 program and the chemical engineering plant cost index (CEPCI) of 580 for the year 2011 (O'Rourke et al., 2011). The FCI of the base case biodiesel plant is $\$ 17,429,160$ and the cost of the novel biodiesel production plant is $\$ 29,276,352$ as shown in Table 4. Land (L) and working capital (WC) are assumed equal to 5\% and $20 \%$ of FCI, respectively. Cost of manufacturing (COM) without depreciation is given by (Turton et al., 2008)

$$
C O M=0.18 F C I+2.73 C_{O L}+1.23\left(C_{U T}+C_{W T}+C_{R M}\right)
$$

where the costs of utilities $\left(C_{U T}\right)$, labor $\left(C_{O L}\right)$, waste treatment $\left(C_{W T}\right)$ and raw materials $\left(C_{R M}\right)$ are shown in Table 4 . Table 4 also shows the total cost of utilities provided by Aspen Plus V7.2 based on $8400 \mathrm{hr} /$ year of the plant operation. The reported costs of low and medium pressure steam, cooling water, and electricity (Seider et al., 2009) are updated using the 2011 CEPCI of 580. Number of employee $\left(N_{O L}\right)$ is estimated by (Turton et al., 2008)

$$
N_{O L}=\left(6.29+31.7 P^{2}+0.23 N_{n p}\right)^{0.5}
$$

where $P$ is the number of processing steps and $N_{n p}$ is the summation of number of equipment such as compressors, towers, reactors, heaters, and exchangers. 
Table 4

Major cost factors of the biodiesel production plant.

\begin{tabular}{|c|c|c|}
\hline & Base case & Novel \\
\hline Fixed capital investment (FCI), \$ & $17,429,160.00$ & $29,276,352.00$ \\
\hline Land $(\mathrm{L}), \$(5 \%$ of FCI $)$ & $871,458.00$ & $1,463,817.60$ \\
\hline Working capital (WC), $\$(20 \%$ of FCI) & $3,485,832.00$ & $5,855,270.40$ \\
\hline Labor, $\$ / \mathrm{hr}$ & $30.00^{*}$ & $30.00^{*}$ \\
\hline Operating labor & 14 & 16 \\
\hline Cost of labor (COL), \$ & $3,528,000.00$ & $4,032,000.00$ \\
\hline Cost of Electricity, $\$ / \mathrm{kW}-\mathrm{h}$ & 0.0666 & 0.0666 \\
\hline Cost of cooling water, $\$ /$ ton & 0.0202 & 0.0202 \\
\hline Cost of 1 bar steam, $\$ / \mathrm{kg}$ & 0.0024 & 0.0024 \\
\hline Cost of 35 bar steam, $\$ / \mathrm{kg}$ & - & 0.0166 \\
\hline Cost of utilities (CUT), $\$$ & $337,421.22$ & $732,699.72$ \\
\hline Waste treatment, $\$ / \mathrm{kg}$ & 0.37 & 0.37 \\
\hline Total cost of waste treatment, $\$$ & $108,123.23$ & $1,042,564.12$ \\
\hline Cost of methanol, $\$$ gal & 0.75 & 0.75 \\
\hline Cost of oil, \$/barrel & 93.00 & 93.00 \\
\hline Cost of $\mathrm{CO}_{2}, \$ / \mathrm{kg}$ & - & 0.045 \\
\hline Cost of $\mathrm{Ca}_{3} \mathrm{La}_{1}, \$ / \mathrm{kg}$ & 150.00 & 150.00 \\
\hline Cost of n-Bu2 $\mathrm{SnO}, \$ / \mathrm{kg}$ & - & 40.00 \\
\hline Cost of raw materials, $\$$ & $47,247,426.66$ & $48,846,767.63$ \\
\hline Cost of manufacturing (COM), $\$$ & $71,431,043.26$ & $78,542,202.08$ \\
\hline Price of FAME, \$/gal & 4.80 & 4.80 \\
\hline Price of crude glycerol, $\$ / \mathrm{kg}$ & 0.30 & 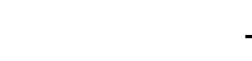 \\
\hline Price of GC, $\$ / \mathrm{kg}$ & - & 2.40 \\
\hline Revenue (R), \$/year & $76,177,228.43$ & $86,950,725.12$ \\
\hline Taxation rate $(\mathrm{t}), \%$ & 35 & 35 \\
\hline Years of operation (n) & 15 & 15 \\
\hline Years of depreciation $(\mathrm{k})$ & $5^{* *}$ & $5^{* *}$ \\
\hline Operational time, $\mathrm{hr} /$ year & 8,400 & 8,400 \\
\hline Interest rate (i), \% & 5 & 5 \\
\hline
\end{tabular}

* Updated using CEPCI $=580$ (Turton et al., 2008); ** Less taxes paid when the project is depreciate as soon as possible. 
The total cost of labor summarized in Table 4 is calculated based on 8400 $\mathrm{hr} /$ year of the plant operation. The cost of waste disposal is $\$ 0.37 / \mathrm{kg}$ (Seider et al., 2009). The price of oil and methanol are $\$ 93.0 /$ barrel and $\$ 0.75 /$ gal, respectively (Tremain, 2011). The current selling price of products is presented in Table 4. With the inclusion of tax incentive and renewable index number, biodiesel producers can get up to $\$ 2.80$ /gallon in addition to the market price of biodiesel (Geiver, 2011; Voegele, 2011), making the selling price of biodiesel approximately equal to $\$ 4.80 /$ gallon. Salvage $(\mathrm{S})$ value is $0 \%$ of FCI (Turton et al., 2008). The useful life of the plants, taxation rate ( $\mathrm{t}$ ), depreciation and interest rate are also presented in Table 4.

The novel biodiesel production plant requires higher capital investment but generates higher revenue due to the value of glycerol carbonate. The book values $(B V)$ are defined by

$$
B V_{k}=F C I-\sum_{1}^{k} d_{k}^{M A C R S}
$$

and are evaluated using the modified accelerated cost recovery system (MACRS) depreciation method for 5 years (Turton et al., 2008).Cash flows $(C F)$ is determined by (Turton et al., 2008)

$C F=\left(R-C O M-d_{k}^{M A C R S}\right)(1-t)+d_{k}^{M A C R S}$

where $R$ is the revenue and $t$ is the tax. In the deterministic model, based on the most likely economic data considered in Table 4, discounted cash flows (DCF) and cumulative discounted cash flows (CDCFs) are estimated. The plot of DCCFs versus years of operation yields the feasibility criteria of net present value (NPV), payback period (PBP), and rate of return (ROR) as shown in Table 5.

\subsection{Stochastic model}

In reality, over the years of operation, the prices of a product, labor, energy, and raw material change leading to fluctuations in the economic data considered in Table 4. Stochastic model uses probability analysis to quantify uncertainty of major economic data. Trapezoidal, normal, and lognormal density cumulative probability density function are often used to describe uncertainty in data. However, triangular cumulative probability function $(P(x))$ is used in this study to reduce calculation complexity (Turton et al., 2008) 


$$
\begin{aligned}
& P(x)=\frac{(x-a)^{2}}{(c-a)(b-a)} \quad \text { for } x \leq b \\
& P(x)=\frac{(b-a)}{(c-a)}+\frac{(x-b)(2 c-x-b)}{(c-a)(c-b)} \quad \text { for } x>b
\end{aligned}
$$

where $a$ is the estimate of the lowest value, $b$ is the most likely value and $c$ is the estimate of the highest value. Since $P(x)$ (random number), $a, b$, and $c$ are known, the above equation can be solved for $x$, which will yield two solutions. However, one will lie outside the interval (lower than $a$ or higher than $c$ ) and will be disregarded.

Here, the uncertainties on the three major economic parameters of revenue (R), cost of manufacturing (COM), and fixed capital investment (FCI) are considered for comparison. Fixed capital investment may vary between $-20 \%$ and $+30 \%$, the cost of manufacturing may vary in the range $-10 \%$ to $+10 \%$, and the product price may vary from $-20 \%$ to $+5 \%$. Random number generated from Rand() function in Microsoft's Excel program is used to assign the probability distributions as shown in Tables 6 and 7 for the base case and novel biodiesel plants, respectively.

\section{Results and discussions}

The market value of bioglycerol drop significantly due to its excess production as a by-product of the biodiesel production plant. Purification of glycerol in a small to medium scale biodiesel production plant is not an option due to high investment in separation units and low rate of return. As a result, direct conversion of glycerol into a value-added chemical, glycerol carbonate, reduces over production of crude glycerol and may improve the economics of the biodiesel plant as shown in Fig. 4. The process also consumes carbon dioxide, which is a renewable feedstock. In addition, glycerol carbonates has wide range of application, which can be used to produces valuable chemicals such as polymers, propylene carbonate, and cyclocarbonate derivatives. 


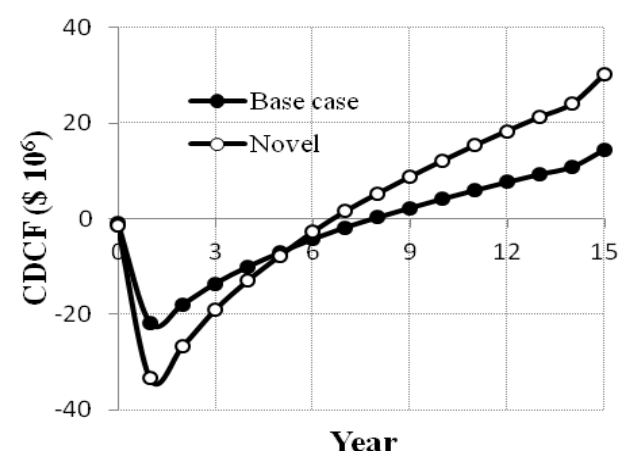

Fig. 4. Comparison of the cumulative discounted cash flow diagram of the base case and novel biodiesel production plants

\section{Table 5}

Discounted profitability criterion of the base case and novel plans.

\begin{tabular}{lll}
\hline & Base & Novel \\
\hline Net present values (NPV, millions) & 15.45 & 28.66 \\
Rate of return (ROR, \%) & 15.58 & 16.56 \\
Payback period (PBP, years) & 4.7 & 4.4 \\
\hline
\end{tabular}

Transesterification of triglyceride and methanol using solid catalyst requires higher methanol/oil molar ratio compared to homogeneous acid or base catalysts. Addition of glycerol carbonate production process directly uses of excess methanol as a solvent in the direct carboxylation reaction. The energy requirement for methanol recovery in flash column F101 is reduced considerably in section 1 of the novel biodiesel production plant compared with the base case biodiesel production plant. Streams R1, R3, and R5 are treated as tear streams in the biodiesel production section of both biodiesel production plants while streams $\mathrm{R} 1, \mathrm{R} 3$, and R7 are treated as tear streams in section 2 of the novel biodiesel production plant.

Fig. 4 shows the discounted cash flow diagrams generated using the deterministic model. As seen from Fig. 4, the net present value of the novel biodiesel plant is $\$ 13.21$ million higher than the base case biodiesel plant at the end of 15-year project. Table 5 shows the results of the feasibility criteria of NPV, 
ROR, and PBP for the base case and novel operations obtained from the deterministic model. Any two of the criteria should be favorable for a feasible operation. The novel operation seems more favorable under current economic data considered in Table 4.

However, by taking into account of the uncertainties even on the values of $\mathrm{R}, \mathrm{COM}$, and FCI only to make predictions may lead to a more realistic economic assessment. Random distribution values of R, COM, and FCI are calculated by using equations 6 and 7. The values of NPV estimated from 20-point Monte-Carlo simulations are summarized in Tables 6 and 7. The cumulative probability curves (Fig. 5) is constructed by the order of the values of NPV from the lowest to highest. Fig. 5 illustrates that the novel biodiesel production plant has around 30\% chance of having a NPV smaller than zero, while the base case plant has around $63 \%$ chance of having a NPV smaller than zero.

Tedious calculations can be avoided by using CAPCOST software to generate Monte Carlo simulation. Table 8 presents the uncertainties of some of the key parameters over the plant life. Fig. 6 presents the cumulative probability distributions obtained 1000-point Monte Carlo simulations for the values of NPV, ROR, and PBP values produced using CAPCOST software based on the uncertainties of parameters shown in Table 8 . The results indicate that the novel biodiesel is about 33 percent more likely profitable compared to the base case biodiesel production plant. The lowest values of NPV for the base case and novel plants are $-\$ 81.9$ and $-\$ 82.9$ million, respectively, while the highest values of NPV for the base case and novel plants are $\$ 112.7$ and $\$ 136.8$ million, respectively. 


\section{Table 6}

Results of the 20-Point Monte-Carlo Simulation of the base case biodiesel production plant (All \$ figures are in millions).

\begin{tabular}{cccccccc}
\hline Run & Rand(1) & R $(\$ / y r)$ & Rand $(2)$ & COM $(\$ / y r)$ & Rand $(3)$ & FCI $(\$)$ & NPV $(\$)$ \\
\hline 1 & 0.4832 & 72.78 & 0.8648 & 74.86 & 0.7464 & 19.26 & -39.00 \\
2 & 0.8738 & 76.96 & 0.3676 & 70.41 & 0.3678 & 17.29 & 16.09 \\
3 & 0.6314 & 74.82 & 0.9560 & 76.46 & 0.1955 & 16.38 & -34.24 \\
4 & 0.1859 & 68.29 & 0.0163 & 65.58 & 0.4916 & 17.81 & -7.11 \\
5 & 0.6757 & 75.14 & 0.0293 & 66.02 & 0.5296 & 18.03 & 31.94 \\
6 & 0.2345 & 69.19 & 0.5288 & 71.64 & 0.5153 & 17.96 & -39.76 \\
7 & 0.0934 & 66.15 & 0.6006 & 72.19 & 0.1780 & 16.27 & -60.50 \\
8 & 0.3741 & 71.36 & 0.6522 & 72.62 & 0.5246 & 18.00 & -32.63 \\
9 & 0.2332 & 69.17 & 0.1710 & 68.47 & 0.2289 & 16.58 & -18.89 \\
10 & 0.1942 & 68.45 & 0.3999 & 70.68 & 0.1244 & 15.89 & -36.62 \\
11 & 0.7793 & 75.98 & 0.7569 & 73.59 & 0.5049 & 17.91 & -10.37 \\
12 & 0.1901 & 68.37 & 0.2976 & 69.80 & 0.4911 & 17.81 & -33.09 \\
13 & 0.3307 & 70.74 & 0.6200 & 72.35 & 0.2198 & 16.53 & -33.56 \\
14 & 0.4769 & 72.70 & 0.7450 & 73.47 & 0.6261 & 18.53 & -30.22 \\
15 & 0.6388 & 74.87 & 0.3710 & 58.13 & 0.3146 & 17.03 & 3.30 \\
16 & 0.6055 & 74.64 & 0.4477 & 71.05 & 0.4308 & 17.56 & -2.32 \\
17 & 0.7401 & 75.64 & 0.5897 & 72.10 & 0.2938 & 16.93 & -2.32 \\
18 & 0.2646 & 69.70 & 0.7430 & 73.45 & 0.9000 & 20.52 & -50.40 \\
19 & 0.1836 & 68.24 & 0.1916 & 68.71 & 0.6765 & 18.82 & -27.87 \\
20 & 0.3330 & 70.77 & 0.5435 & 71.75 & 0.9147 & 20.69 & -32.89 \\
\hline $\mathrm{R}=$ Revenue, COM $=$ Cost of manufacturing, FCI = Fixed capital investment, NPV \\
Net present value & & & & & &
\end{tabular}




\section{Conclusions}

This study shows that addition of glycerol carbonate production not only results in a more environmentally friendly process as it consumes renewable feedstock of carbon dioxide but it is also an economical process as it converts two by-products into a value-added bioproduct. Using deterministic model prediction, the net present value of the novel biodiesel production plant is $\$ 13.21$ million higher than the base case biodiesel plant at the end of 15-year project. Also, stochastic model has predicted that addition of glycerol carbonate production may increase the probability of getting positive net present value by about $33 \%$ for the novel biodiesel plant.

\section{Table 7}

Results of the 20-Point Monte-Carlo Simulation of the novel biodiesel production plant (All $\$$ figures are in millions).

\begin{tabular}{cccccccc}
\hline Run & Rand $(1)$ & R $(\$ / \mathrm{yr})$ & Rand $(2)$ & COM $(\$ / y r)$ & Rand $(3)$ & FCI $(\$)$ & NPV $(\$)$ \\
\hline 1 & 0.3616 & 81.25 & 0.3107 & 76.88 & 0.8722 & 34.01 & -15.61 \\
2 & 0.9395 & 88.91 & 0.9007 & 82.90 & 0.2910 & 28.42 & -2.83 \\
3 & 0.5543 & 84.81 & 0.5161 & 78.67 & 0.6955 & 31.80 & -3.52 \\
4 & 0.0984 & 75.66 & 0.6489 & 79.81 & 0.5412 & 30.38 & -65.84 \\
5 & 0.0059 & 71.05 & 0.3401 & 77.17 & 0.4723 & 29.78 & -76.80 \\
6 & 0.3584 & 81.20 & 0.1255 & 74.62 & 0.4199 & 29.42 & 1.83 \\
7 & 0.8455 & 87.48 & 0.2510 & 76.25 & 0.0019 & 23.82 & 33.98 \\
8 & 0.7484 & 86.42 & 0.5151 & 78.66 & 0.8084 & 33.10 & 5.46 \\
9 & 0.1292 & 76.55 & 0.9478 & 83.86 & 0.7461 & 32.35 & -87.50 \\
10 & 0.5312 & 84.64 & 0.3417 & 77.18 & 0.2071 & 27.63 & 7.92 \\
11 & 0.4873 & 83.13 & 0.8820 & 82.58 & 0.4310 & 29.50 & -37.01 \\
12 & 0.8294 & 87.28 & 0.6050 & 79.42 & 0.2673 & 28.21 & 9.46 \\
13 & 0.8010 & 86.96 & 0.8657 & 82.33 & 0.5206 & 30.21 & -12.41 \\
14 & 0.6276 & 85.37 & 0.9898 & 85.27 & 0.9671 & 36.00 & -45.12 \\
15 & 0.8279 & 87.27 & 0.8576 & 82.20 & 0.2792 & 28.31 & -7.47 \\
16 & 0.8473 & 87.50 & 0.4284 & 77.96 & 0.0075 & 24.22 & 23.03 \\
17 & 0.1160 & 76.18 & 0.6440 & 79.77 & 0.5091 & 30.11 & -62.15 \\
18 & 0.8731 & 87.84 & 0.0809 & 73.85 & 0.2332 & 27.89 & 48.54 \\
19 & 0.5612 & 84.86 & 0.7552 & 80.90 & 0.3597 & 28.97 & -15.12 \\
20 & 0.2645 & 79.56 & 0.9014 & 82.91 & 0.7252 & 32.12 & -62.88 \\
\hline $\mathrm{R}=$ Revenue, COM $=$ Cost of manufacturing, FCI = Fixed capital investment, NPV= Net present \\
value & & & & & & & \\
& & & & & & &
\end{tabular}




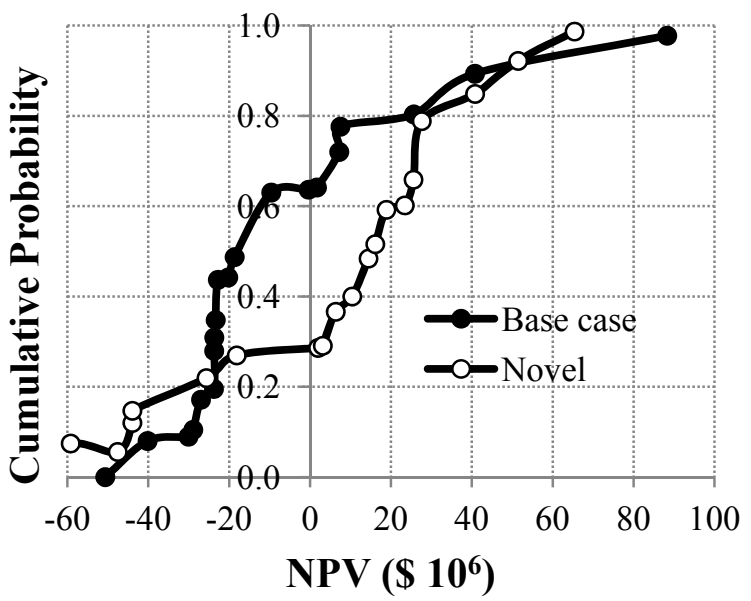

Fig. 5. Comparison of the cumulative probability of NPV obtained from the stochastic model using the uncertainties on revenue, fixed capital investment and cost of manufacturing only.

Table 8

Uncertainties on some key parameters

\begin{tabular}{lcccc}
\hline & $\begin{array}{c}\text { Base case } \\
\text { Base value (b) }\end{array}$ & $\begin{array}{c}\text { Novel } \\
\text { base value (b) }\end{array}$ & Lower limit (a) & Upper limit (c) \\
\hline FCI & $17,429,160$ & $29,276,352$ & $-20 \%$ & $30 \%$ \\
Price of product, \$ & $76,177,228$ & $86,950,725$ & $-10 \%$ & $20 \%$ \\
Working capital, \$ & $3,485,832$ & $5,855,270$ & $-10 \%$ & $15 \%$ \\
Income tax rate, $\%$ & 35 & 35 & $-5 \%$ & $15 \%$ \\
Interest rate, $\%$ & 5 & 5 & $-5 \%$ & $5 \%$ \\
Raw material price, $\$$ & $47,247,426$ & $48,846,767$ & $-10 \%$ & $20 \%$ \\
\hline
\end{tabular}




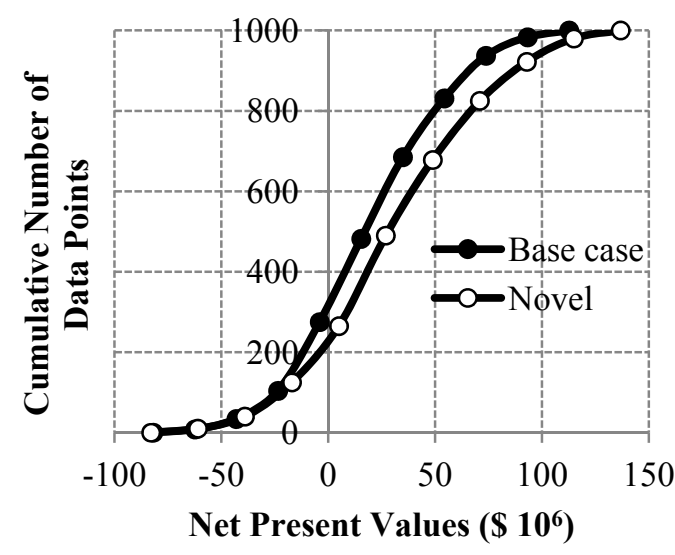

(a)

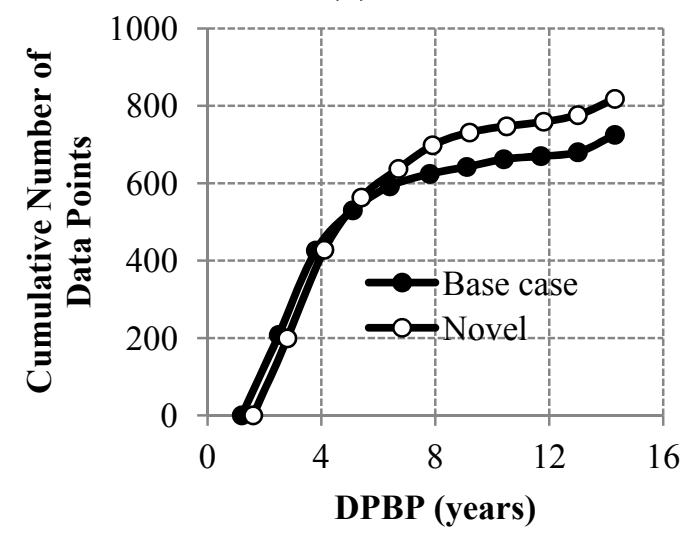

(c)

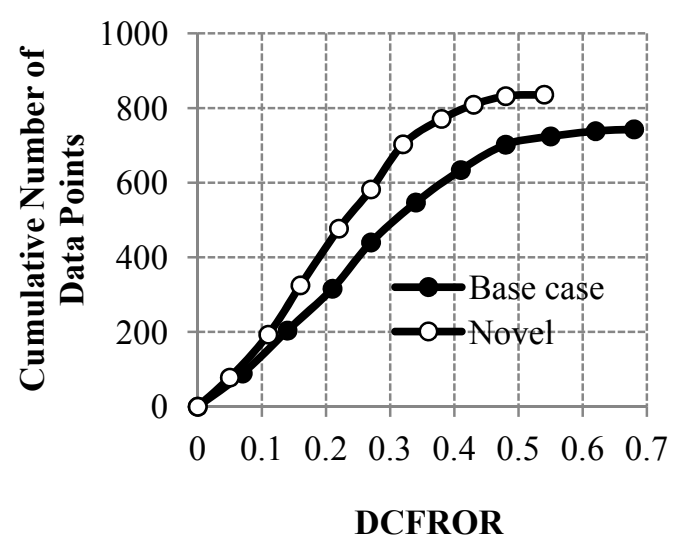

(b)

Fig. 6. 1000-point Monte Carlo simulation on; (a) net present values (NPV), (b) discounted cash flow rate of return (DCFROR), (c) discounted payback period (DPBP). 


\section{Nomenclature}

$a$ : estimate of the lowest value

$b$ : most likely value

$B V$ : Book values

$c$ : estimates of the highest value

$C_{B m, i}^{o}$ : Bare module cost for equipment at base conditions

$C_{G R}$ : Grassroots cost

$C D C F$ : cumulative discounted cash flow

CEPCI: Chemical engineering plant cost index

$C F$ : Cash flows

COM: Cost of manufacturing

$d_{k}^{\text {MACRS }}$ : Modified accelerated cost recovery system depreciation method

$D C F$ : Discounted cash flow

DCFROR: Discounted cash flow rate of return

$D P D P$ : Discounted payback period

$F A M E$ : Fatty acid methyl ester

FCI: Fix capital investment

$L$ : Land

$M A C R S$ : Modified accelerated cost recovery system

$N_{n p}$ : Summation of number of equipments

$N P V:$ Net present value

$N_{O L}$ : Number of employee

$P$ : Number of processing steps

$P(x)$ : Random number

PBP: Payback Period

$R O R$ : Rate of return

$S:$ Salvage

$x$ : parameters such as $\mathrm{R}, \mathrm{COM}$, and FCI

$W C$ : Working capital 


\section{References}

Aresta, M., Dibenedetto, A., Nocito, F., et al., 2006. A study on the carboxylation of glycerol to glycerol carbonate with carbon dioxide: The role of the catalyst, solvent and reaction conditions. J. Mol. Catal. A Chem. 257, 149153.

Bandyopadhyay, S., Malik R.K., Shenoy, U.V., 1998. Temperature-enthalpy curve for energy targeting of distillation columns. Comput. Chem. Eng. 22, 1733-1744.

Chun-Hui, Z., Jorge, N.B., Yong-Xian, F., et al., 2008. Chemoselective catalytic conversion of glycerol as a biorenewable source to valuable commodity chemicals. Chem. Soc. Rev. 37, 527-549.

Demirel, Y., 2006. Retrofit of distillation columns using thermodynamic analysis. Sep. Sci. Technol. 41, 791-817.

Di Serio, M., Tesser, R., Penqmei, L., et al., 2008. Heterogeneous catalysts for biodiesel production. Energy Fuels 22, 207-217.

Dibenedetto, A., Angelini, A., Aresta, M., 2011. Converting wastes into added value products: from glycerol to glycerol carbonate, glycidol and epichlorohydrin using environmentally friendly synthetic routes. Tetrahedron 67, 1308-1313.

Geiver, L., 2011. Biodiesel RIN prices reach new highs, could be headed higher. Biodiesel Magazine. www.biodieselmagazine.com

George, J., Patel, Y., Pillai, S., et al., 2009. Methanol assisted selective formation of 1,2-glycerol carbonate from glycerol and carbon dioxide using ${ }^{n} \mathrm{Bu} 2 \mathrm{SnO}$ as a catalyst. J. Mol. Catal. A Chem. 304, 1-7.

Lee, J-S., Saka, S., 2010. Biodiesel production by heterogeneous catalyst and supercritical technologies. Bioresour. Technol. 101, 7191-7200.

Nguyen, N., Demirel, Y., 2010a. Carboxylation of glycerol in a biodiesel plant. AIChE Annual. Meeting. Conf. Proc. Nov 7-12, Salt Lake City, Utah.

Nguyen, N., Demirel, Y., 2010b. Retrofit of distillation columns in biodiesel production plants. Energy 35, 1625-1632.

Nguyen, N., Demirel, Y., 2011. Using thermally coupled reactive distillation columns in biodiesel production. Energy 36, 4838-4847.

Olga, G-P.M., Rosas, J.M., Bedia, J., et al., 2009. Recent inventions in glycerol transformations and processing. Recent Pat. Chem. Eng. 2, 11-21.

O’Rourke, M., Marshall, R., Lozowski, D., et al., www.che.com. Accessed on April 12, 2011.

Rajabathar, J., Ming, K.W., 2009. Review of recent developments in solid acid, base, and enzyme catalysts (heterogeneous) for biodiesel production via transesterification. Ind. Eng. Chem. Res. 48, 6162-6172. 
Seider, W.D, Seader, J.D., Lewin, D.R., 2009. Product and process design principles, third ed. John Wiley \& Sons, Inc., New Jersey.

Sharma, Y.C., Singh, B., Korstad, J., 2010. Advancements in solid acid catalysts for ecofriendly and economically viable synthesis of biodiesel. Biofuel Bioprod. Biorefining 5, 69-92.

Tremain, S., www.biodiesel.org. Accessed on April 15, 2011.

Turton, R., Bailie, R.C., Whiting, W.B., 2008. Analysis, synthesis, and design of chemical processes, third ed. Prentice Hall, Massachusetts.

Vieville, C., Yoo, J.W., Pelet, S., et al., 1998. Synthesis of glycerol carbonate by direct carbonatation of glycerol in supercritical $\mathrm{CO}_{2}$ in the presence of zeolites and ion exchange resins. Catal. Lett. 56, 245-247.

Voegele, E., 2011. Legislation would alter biodiesel tax credit. Biodiesel Magazine. www.biodieselmagazine.com

Yan, S., Kim, M., Salley, S.O., et al., 2009. Oil transesterification over calcium oxides modified with lanthanum. Appl Catal A Gen 360, 163-170.

Yan, S., Dimaggio, C., Mohan, S., et al., 2010a. Advancements in heterogeneous catalysis for biodiesel synthesis. Top. Catal. 53, 721-736.

Yan, S., Kim, M., Mohan, S., et al., 2010b. Effects of preparative parameters on the structure and performance of $\mathrm{Ca}-\mathrm{La}$ metal oxide catalysts for oil transesterification. Appl Catal A Gen 373, 104-111.

Zabeti, M., Wan Daud, W.M.A., Aroua, M.K., 2009. Activity of solid catalysts for biodiesel production: A review. Fuel Process Technol 90, 770-777.

Zhang, Y., Dubé, M.A., McLean, D.D., et al., 2003. Biodiesel production from waste cooking oil: 2. Economic assessment and sensitivity analysis. Bioresour. Technol. 90, 229-240.

Zheng, Y., Chen, X., Shen Y., 2008. Commodity chemicals derived from glycerol, an important biorefinery feedstock. Chem. Rev. 108, 5253-5277. 